\title{
High-yield maize with large net energy yield and small global warming intensity
}

\author{
Patricio Grassini ${ }^{1}$ and Kenneth G. Cassman \\ Department of Agronomy and Horticulture, University of Nebraska, Lincoln, NE 68583-0915
}

Edited by Peter M. Vitousek, Stanford University, Stanford, CA, and approved November 29, 2011 (received for review October 5, 2011)

\begin{abstract}
Addressing concerns about future food supply and climate change requires management practices that maximize productivity per unit of arable land while reducing negative environmental impact. Onfarm data were evaluated to assess energy balance and greenhouse gas (GHG) emissions of irrigated maize in Nebraska that received large nitrogen $(\mathrm{N})$ fertilizer $\left(183 \mathrm{~kg}\right.$ of $\left.\mathrm{N} \cdot \mathrm{ha}^{-1}\right)$ and irrigation water inputs $\left(272 \mathrm{~mm}\right.$ or $\left.2,720 \mathrm{~m}^{3} \mathrm{ha}^{-1}\right)$. Although energy inputs (30 $\mathrm{GJ} \cdot \mathrm{ha}^{-1}$ ) were larger than those reported for US maize systems in previous studies, irrigated maize in central Nebraska achieved higher

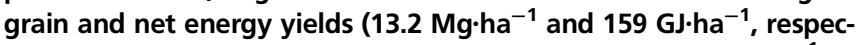
tively) and lower GHG-emission intensity (231 $\mathrm{kg}$ of $\mathrm{CO}_{2} \mathrm{e} \cdot \mathrm{Mg}^{-1}$ of grain). Greater input-use efficiencies, especially for $\mathrm{N}$ fertilizer, were responsible for better performance of these irrigated systems, compared with much lower-yielding, mostly rainfed maize systems in previous studies. Large variation in energy inputs and GHG emissions across irrigated fields in the present study resulted from differences in applied irrigation water amount and imbalances between applied $\mathbf{N}$ inputs and crop $\mathbf{N}$ demand, indicating potential to further improve environmental performance through better management of these inputs. Observed variation in $\mathrm{N}$-use efficiency, at any level of applied $\mathrm{N}$ inputs, suggests that an $\mathrm{N}$-balance approach may be more appropriate for estimating soil $\mathrm{N}_{2} \mathrm{O}$ emissions than the Intergovernmental Panel on Climate Change approach based on a fixed proportion of applied N. Negative correlation between GHG-emission intensity and net energy yield supports the proposition that achieving high yields, large positive energy balance, and low GHG emissions in intensive cropping systems are not conflicting goals.
\end{abstract}

agro-ecosystem | food security | crop intensification | land use change | environmental footprint

$\mathbf{H}$ igh-yield cropping systems require fossil-fuel inputs to substitute human and animal labor and to maximize capture and conversion of solar radiation into crop biomass $(1,2)$. Inputs to agricultural systems that require fossil fuel in their manufacturing process include fertilizer, seed, pesticides, and machinery. Fossil fuel also is required for application of inputs and for field operations, irrigation pumping, and grain drying. Fossil-fuel inputs can be expressed in terms of their embodied energy, that is, the energy required for their synthesis, packaging, transport, and use in a crop production field $(1,3)$. Because fossil fuel combustion results in greenhouse gas (GHG) emissions, energy inputs also can be expressed in terms of global warming potential (GWP) $(4,5)$. Although GWP can be expressed per unit of crop production area, it also can be expressed per unit of grain yield (GWP intensity; GWPi), which recognizes the potential for indirect land use change and associated GWP from clearing of carbon-rich natural ecosystems for crop production (6-8).

Although it has been speculated that the efficiency with which applied inputs result in increased yield can be greater in intensively managed high-yield cropping systems than in their lowinput low-yield counterparts because of optimization of growing conditions in the former (9), this hypothesis has not been evaluated in actual cropping systems where farmer's yields approach yield potential.* The US Corn Belt, including parts of the Great Plains in South Dakota, North Dakota, Nebraska, and Kansas, accounts for $33 \%$ of global maize production. Of total US maize, $\approx 13 \%$ is produced with irrigation on $\approx 3.2$ Mha with the majority grown in Nebraska (11). Energy-use efficiency of maize in the US Corn Belt has increased steadily in recent decades as a result of rising grain yield without increases in amounts of applied $\mathrm{N}$ fertilizer and applied irrigation, widespread adoption of conservation tillage practices and center-pivot systems to replace less efficient gravity irrigation, and increasing efficiency in manufacturing of agricultural inputs $(12,13)$.

Field experiments on irrigated maize have shown that achieving high yields and high efficiencies, together, with relatively low GWP, is possible when applied inputs are precisely managed in time and space $(14,15)$, but the extent to which farmers can achieve such precise management is not known. Likewise, there is a general notion that input-use efficiency of high-yield cropping systems is low, resulting in negative energy balances, high GWP, and degradation of soil and water quality $(16,17)$. In part, such perceptions are based on previous studies that had several deficiencies, including: $(i)$ obsolete embodied energy and GHG emissions factors for agricultural inputs, (ii) obsolete values for grain yield and actual crop management practices with regard to $\mathrm{N}$ fertilizer rates, irrigation, and tillage, (iii) use of metrics that do not weight energy inputs or GWP in relation to yield level, and (iv) lack of clarity on methods used to estimate energy inputs or GHG emissions and system boundaries $(18,19)$. Hence, accurate and transparent estimates of on-farm energy balance and GWP for irrigated maize in the US Corn Belt are not available.

Management practices influence energy balance and GWP by amounts and efficiencies of applied inputs and yield level (1). Given concerns about the cost of energy and climate change, agriculture is challenged by the need to identify management systems that maximize productivity with high energy-use efficiency and low GWP $(2,20)$. Addressing this challenge using a structured experimental approach, however, requires factorial experiments performed over many years at multiple locations $(6,21)$. Because this approach is very costly and there are few opportunities for long-term funding to support such efforts, most research on energy balance and GWP of agricultural systems has relied on data from aggregate agricultural statistics or data gathered from a relatively small number of selected farms $(3,22)$. An alternative is to use farmer-reported databases, collected over a large population of field-years, to perform direct analysis of on-farm energy balance and GWP, and to use the variation in management

Author contributions: P.G. and K.G.C. designed research, performed research, analyzed data, and wrote the paper.

The authors declare no conflict of interest.

This article is a PNAS Direct Submission.

Freely available online through the PNAS open access option.

${ }^{1}$ To whom correspondence should be addressed. E-mail: patricio.grassini@huskers.unl. edu.

This article contains supporting information online at www.pnas.org/lookup/suppl/doi:10 1073/pnas.1116364109/-/DCSupplemental.

*Yield potential is defined as the yield obtained with an adapted cultivar when limitations from nutrients, water deficit, pests and disease are effectively controlled (10). In irrigated systems, yield potential is determined by solar radiation and temperature regime during the growing season. 
practices within these data to identify those that give high yields, high input use efficiencies, and low GWPi.

The central hypothesis of this work is that it is possible for farmers to achieve a large positive energy balance with relatively low GWPi in high-input, high-yield maize systems. To test this hypothesis, farmer-reported data collected from the Tri-Basin Natural Resources District (NRD) in central Nebraska (SI Text, S1) were used to $(i)$ quantify energy balance and GWP of irrigated maize, (ii) compare these parameters against previous published values for maize systems, and (iii) identify and quantify the impact of energy-saving and GWP-reducing management tactics that could achieve these reductions without yield loss. Additional details about sources of data and methods are provided in supplemental materials.

\section{Results and Discussion}

Soil $\mathbf{N}_{\mathbf{2}} \mathbf{O}$ Emissions from Irrigated Maize. Separate estimates of soil $\mathrm{N}_{2} \mathrm{O}$ emissions were calculated by following two methods: the " $\mathrm{N}$ input-driven approach" developed by the Intergovernmental Panel on Climate Change (IPCC; ref. 23), and an "N-surplus-driven approach," recently proposed by van Groenigen et al. (24) (SI Text, S2). The $\mathrm{N}$-input approach assumes that $\mathrm{N}_{2} \mathrm{O}$ emissions represent a constant proportion of applied $\mathrm{N}$ inputs plus $\mathrm{N}$ in crop residues, which does not account for tremendous variability in the efficiency with which applied $\mathrm{N}$ is used by the crop across fields, crops, and regions (12). In contrast, van Groenigen et al. provide strong evidence that $\mathrm{N}_{2} \mathrm{O}$ emissions can be more accurately estimated from the magnitude of $\mathrm{N}$ surplus, which is defined as the difference between $\mathrm{N}$ inputs and crop $\mathrm{N}$ uptake. In this study, applied $\mathrm{N}$ inputs were calculated as the sum of applied $\mathrm{N}$ fertilizer, $\mathrm{N}-\mathrm{NO}_{3}{ }^{-}$in applied irrigation water, and $\mathrm{N}$ in applied manure, which account for $81 \%, 15 \%$, and $4 \%$, respectively, of total $\mathrm{N}$ input (SI Text, S2).

With few exceptions, estimated $\mathrm{N}_{2} \mathrm{O}$ emissions were consistently larger using the $\mathrm{N}$-input approach across the range of $\mathrm{N}$ fertilizer rates applied to irrigated maize fields in the Tri-Basin NRD (Fig. 1A). In a small number of fields that received $>225 \mathrm{~kg}$

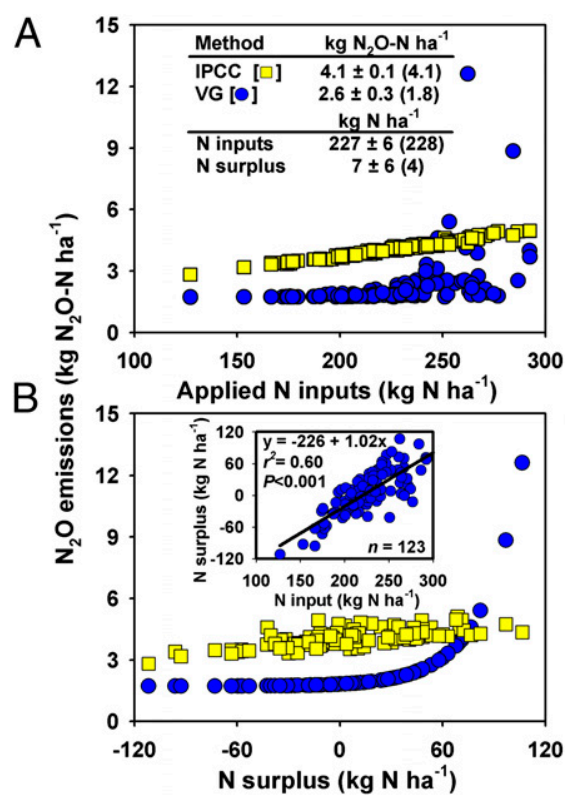

Fig. 1. Soil $\mathrm{N}_{2} \mathrm{O}$ emissions of irrigated maize plotted against applied nitrogen $(\mathrm{N})$ inputs $(A)$ and $\mathrm{N}$ surplus $(B) . \mathrm{N}_{2} \mathrm{O}$ emissions were estimated by following IPCC N-input [ $\square$ (23)] or van Groenigen et al. N-surplus approach (VG; ๑; ref. 24). Average $( \pm \mathrm{SE}) \mathrm{N}_{2} \mathrm{O}$ emissions, $\mathrm{N}$ inputs, and $\mathrm{N}$ surplus (medians in parenthesis) are shown. $B$ Inset shows the relationship between $\mathrm{N}$ surplus and applied $\mathrm{N}$ inputs. of $\mathrm{N} \cdot \mathrm{ha}^{-1}$, however, greater emissions were estimated by the $\mathrm{N}$ surplus approach. However, despite a high average rate of $\mathrm{N}$ fertilization, $76 \%$ of the fields had an $\mathrm{N}$ surplus $<50 \mathrm{~kg} \cdot \mathrm{ha}^{-1}$ so that $\mathrm{N}_{2} \mathrm{O}$ emissions by the $\mathrm{N}$-surplus method were smaller than emissions estimated with the $\mathrm{N}$-input approach (Fig. $1 B$ ). Large $\mathrm{N}$ surplus $\left(>50 \mathrm{~kg}\right.$ of $\left.\mathrm{N} \cdot \mathrm{ha}^{-1}\right)$ resulted from a combination of large $\mathrm{N}$ inputs and relatively low grain yields. Although there was a positive correlation between $\mathrm{N}$ surplus and the level of $\mathrm{N}$ input, large variation in $\mathrm{N}$ surplus was observed at any level of applied $\mathrm{N}$ input due to variation across fields and years in N-use efficiency (NUE, kg of grain per kg of applied N, also called partial factor productivity for $\mathrm{N}$ fertilizer; ref. 12) (Fig. 1B, Inset). Median values for direct $\mathrm{N}_{2} \mathrm{O}$ emissions from irrigated maize in this study was 1.6 and $3.3 \mathrm{~kg} \mathrm{~N}$ O-N.ha ${ }^{-1}$ when using N-surplus and $\mathrm{N}$-input approach, respectively (see SI Text, S2 for distinction between direct and indirect $\mathrm{N}_{2} \mathrm{O}$ emissions). The $\mathrm{N}$-surplus approach median value is similar to annual direct $\mathrm{N}_{2} \mathrm{O}$ emissions of $1.9 \mathrm{~kg} \mathrm{~N} \mathrm{~N}_{2} \mathrm{O}-\mathrm{N} \cdot \mathrm{ha}^{-1}$ measured in a well-managed irrigated continuous maize system in Nebraska that achieved grain yields similar to those in the Tri-Basin NRD (15).

The proposition that $\mathrm{N}$ losses from applied fertilizer tend to be small when the $\mathrm{N}$ supply is balanced by crop uptake is scientifically robust and supported by published data $(12,15,24,25)$. Hence, reported GWP in the following sections were calculated based on $\mathrm{N}_{2} \mathrm{O}$ emissions estimated by the $\mathrm{N}$ surplus approach unless stated otherwise.

Table 1. Average 3-y (2005-2007) applied inputs (and percentage of total energy input), total fossil-fuel energy input, grain yield and interannual coefficient of variation, fertilizer nitrogen-use efficiency, water productivity, and conversion efficiency from solar radiation into grain or total biomass based on data collected from 123 irrigated maize fields in Tri-Basin NRD

Inputs

Rate (per ha)

\begin{tabular}{lc}
\hline $\mathrm{N}$ fertilizer, $\mathrm{kg}$ of $\mathrm{N}$ & $183(32 \%)$ \\
$\mathrm{P}$ fertilizer, $\mathrm{kg}$ of $\mathrm{P}_{2} \mathrm{O}_{5}$ & $43(1 \%)$ \\
$\mathrm{K}$ fertilizer, $\mathrm{kg}$ of $\mathrm{K}_{2} \mathrm{O}$ & $11(<1 \%)$ \\
Herbicides, $\mathrm{kg}$ of a.i. & $2.4(3 \%)$ \\
Insecticides, $\mathrm{kg}$ of a.i. & $0.3(<1 \%)$ \\
Seed, $\mathrm{kg}$ & $25(1 \%)$ \\
Machinery, MJ & $464(2 \%)$ \\
Fuel use for on-farm operations, ${ }^{*} \mathrm{~L}$ & \\
$\quad$ Field operations & $63(9 \%)$ \\
$\quad$ Irrigation pumping & ${ }^{\dagger}$ \\
$\quad$ Grain drying & $324(42 \%)$ \\
$\quad$
\end{tabular}

Energy inputs, GJ.ha ${ }^{-1}$

30.0

Grain yield, Mg.ha ${ }^{-1}$

$13.2(\mathrm{CV}=3 \%)$

$\mathrm{NUE}^{\ddagger}{ }^{\ddagger} \mathrm{kg}$ of grain $\mathrm{kg}^{-1}$ of $\mathrm{N}$ fertilize

WP, ${ }^{\S} \mathrm{kg}$ of grain. $\mathrm{mm}^{-1}$ of water supply

PAR conversion efficiency, $\%$

Grain

1.4

Total dry matter

3.3

a.i., active ingredient; CV, coefficient of variation; NUE, fertilizer nitrogen-use efficiency; WP, water productivity.

*Expressed as diesel equivalents (\$3).

${ }^{\dagger}$ Average 3-y (2005-2007) annual applied irrigation amount was $272 \mathrm{~mm}$. ${ }^{ \pm}$Ratio of grain yield to applied $\mathrm{N}$ fertilizer.

${ }^{\S}$ Ratio of grain yield to total water supply. Total water supply includes plant available soil water at planting and in-season rainfall plus applied irrigation water.

"Ratio of embodied energy in grain or total dry matter to total incident photosynthetically active solar radiation (PAR) from sowing-to-maturity. 


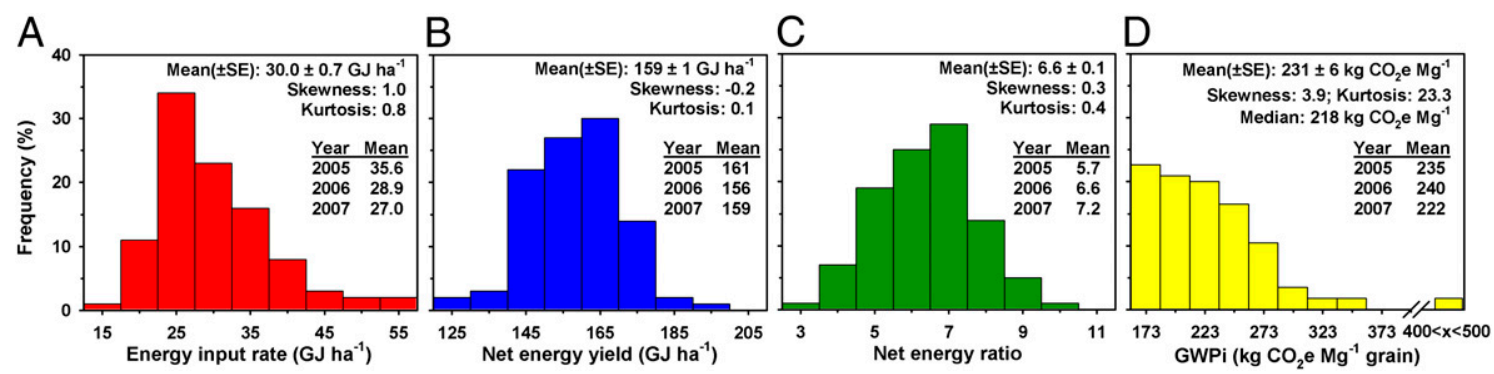

Fig. 2. Frequency distribution of fossil-fuel energy input $(A)$, net energy yield $(B)$, net energy ratio $(C)$, and global warming potential intensity (GWPi) $(D)$ based on data from 123 irrigated maize fields.

Energy Balance and Greenhouse Gas Emissions. Large energy inputs to irrigated maize in the study area are associated with high and stable grain yields (Table 1). Irrigated maize yield was 2.2-fold greater and much less variable across years than lower-yielding, less intensively managed rainfed maize in the same region [mean rainfed yield $\pm \mathrm{SE}=5.9 \pm 0.8 \mathrm{Mg} \cdot \mathrm{ha}^{-1}$; interannual coefficient of variation $(\mathrm{CV})=23 \%$ ]. Moreover, irrigated maize in the TriBasin NRD achieved, on average, $89 \%$ of its estimated yield potential as documented in a previous study (26). Although $\mathrm{N}$ fertilizer inputs were well above $\mathrm{N}$ rates reported in previous studies of energy balance and GWP in US maize systems, NUE achieved by irrigated maize producers in the current study was much higher than previous published values (Table S1). Likewise, although total water supply was $41 \%$ greater with irrigation compared with rainfed maize in the Tri-Basin NRD, water productivity of irrigated maize was $60 \%$ higher (14.0 vs. $8.8 \mathrm{~kg}$.ha$\mathrm{mm}^{-1}$, respectively) (27). Remarkably, conversion efficiency from solar radiation to total dry matter of $3.3 \%$ estimated for irrigated maize in the Tri-Basin NRD compares well with highest observed conversion efficiencies (range: 3.9-5.2\%) for field-grown irrigated maize grown with optimal management practices $(28,29)$.

Irrigated maize received relatively large fossil-fuel energy inputs (mean: $30.0 \mathrm{GJ} \cdot \mathrm{ha}^{-1}$ ) and also achieved a large positive energy balance [average net energy yield (NEY) and net energy ratio (NER) of $159 \mathrm{GJ} \cdot \mathrm{ha}^{-1}$ and 6.6, respectively], with substantial variation across site-years (Fig. $2 A-C$ and Fig. $3 A$ and $C$ ). The largest fossil fuel inputs came from embodied energy in $\mathrm{N}$ fertilizer and from fuel use for irrigation pumping, which represented $32 \%$ and $42 \%$ of total energy inputs, respectively (Table 1). Average energy inputs for irrigated maize production in the Tri-Basin NRD was much higher than previous reported energy inputs for US maize systems that were based mostly on rainfed production (Fig. $3 A$ and Table $\mathrm{S} 1$ ). Hence, previous studies included little or no energy inputs associated with irrigation pumping and much less energy associated with $\mathrm{N}$ fertilizer because of lower fertilizer rates in rainfed systems. Average NEY of irrigated maize in Tri-Basin
NRD was the highest among published studies, whereas NER was equal or higher than published values except for 2 of 11 cases.

Despite relatively large fossil-fuel energy inputs, irrigated maize exhibited low GWPi (Fig. $2 D$ ). On average, $\mathrm{CO}_{2}, \mathrm{~N}_{2} \mathrm{O}$, and $\mathrm{CH}_{4}$ emissions, expressed as $\mathrm{CO}_{2}$ equivalents $\left(\mathrm{CO}_{2} \mathrm{e}\right)$, accounted for $63 \%, 36 \%$, and $1 \%$ of GWP in these irrigated maize fields (mean $\pm \mathrm{SE}=3,001 \pm 67 \mathrm{~kg}$ of $\mathrm{CO}_{2} \mathrm{e} \cdot \mathrm{ha}^{-1}$ ). The largest impact on GWP came from soil $\mathrm{N}_{2} \mathrm{O}$ emissions associated with applied $\mathrm{N}$ fertilizer (34\%), fuel use for irrigation $(29 \%)$, manufacture and transportation of $\mathrm{N}$ fertilizer $(17 \%)$, and fuel use for grain drying and field operations (13\%). Frequency distribution of GWPi deviated significantly from normality as a result of exponential increase in soil $\mathrm{N}_{2} \mathrm{O}$ emissions at $\mathrm{N}$ surplus values $>50 \mathrm{~kg}$ of $\mathrm{N} \cdot \mathrm{ha}^{-1}$ (Fig. $1 B$ ). Although GWP per unit area of irrigated maize in the Tri-Basin NRD was within the upper range of published values for maize systems, average GWPi of $231 \mathrm{~kg}$ of $\mathrm{CO}_{2} \mathrm{e} \cdot \mathrm{Mg}^{-1}$ of grain and GWP per unit energy input of $103 \mathrm{~kg}$ of $\mathrm{CO}_{2} \mathrm{e} \cdot \mathrm{GJ}^{-1}$ were the lowest among published values for US maize systems (Fig. $3 B$ and Table S1). Using the IPCC Ninput approach to calculate $\mathrm{N}_{2} \mathrm{O}$ emissions gave GWP and GWPi $28 \%$ higher than values based on $\mathrm{N}_{2} \mathrm{O}$ emissions with the $\mathrm{N}$-surplus method (Fig. S1 and Table S1).

Impact of Management Practices on Energy Balance and Greenhouse Gas Emissions. Energy balance and GWP were calculated for irrigated maize with different combinations of irrigation system, tillage method, and crop rotation based on actual reported values in the Tri-Basin NRD dataset (Fig. 4). Energy inputs in fields under pivot irrigation and some form of reduced tillage (no-till, ridge-till, or strip-still, which are also called conservation tillage methods) were lower than in fields under surface irrigation and conventional disk tillage, respectively, mostly because of energy savings from irrigation. Applied irrigation was $41 \%$ and $20 \%$ less in fields under pivot irrigation and reduced tillage, respectively, compared with their counterparts under surface irrigation and conventional tillage (27). Apparent advantage of fewer tillage operations was partially
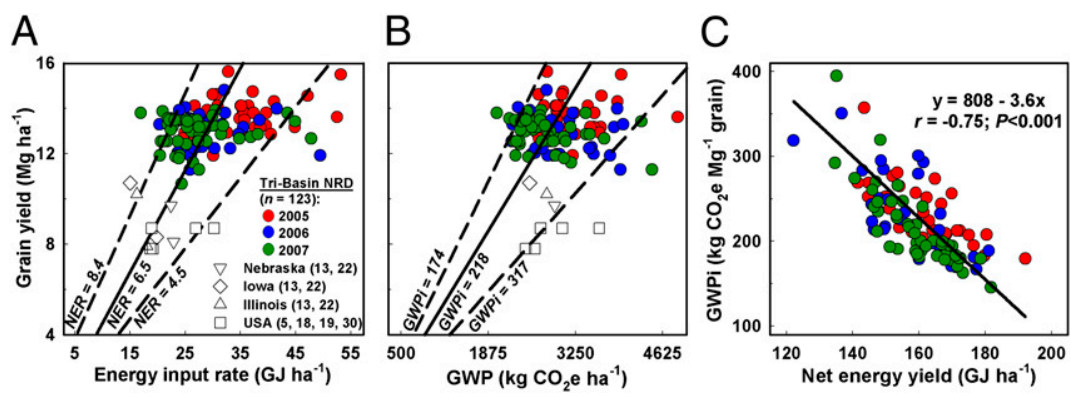

Fig. 3. Maize grain yield plotted against fossil-fuel energy inputs ( $A$ ) and GWP (B). Lines indicate average 3-y median (solid line) and fifth and 95th percentiles (dashed lines) for NER and GWPi calculated for irrigated maize in Tri-Basin NRD. Published data for other US maize systems are shown for comparison (open symbols; Table S1). (C) Relationship between GWPi and net energy yield for irrigated maize in Tri-Basin NRD. 


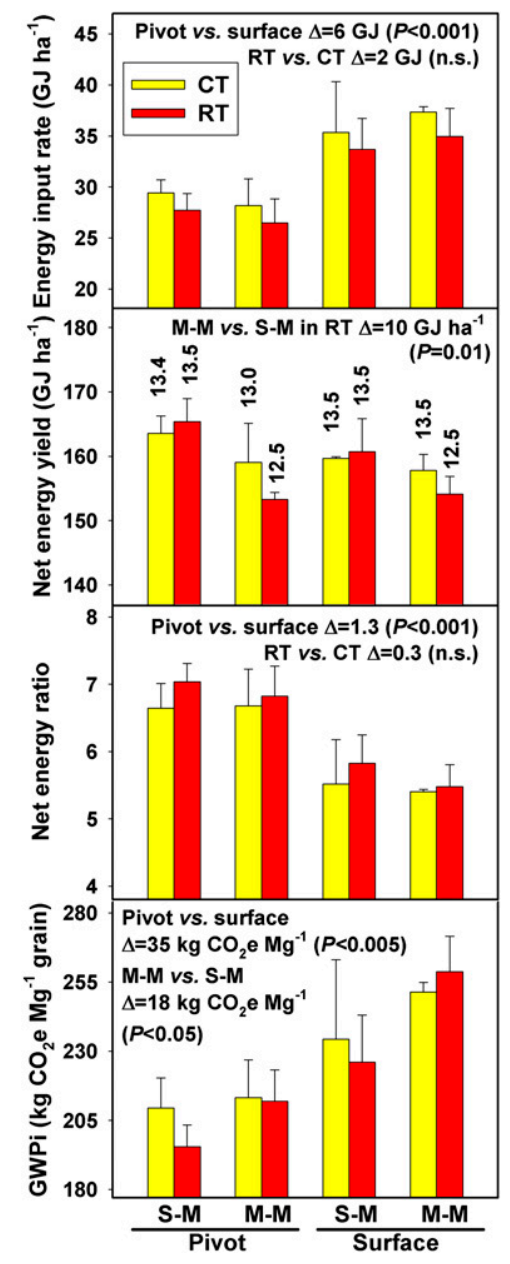

Fig. 4. Average $( \pm \mathrm{SE})$ energy input rate, net energy yield, net energy ratio, and GWPi of irrigated maize under different combinations of: irrigation system (pivot; surface), crop rotation [maize after maize (M-M) or maize after soybean (S-M)], and tillage method [conventional (CT); reduced till (RT)] Maize grain yields $\left(\mathrm{Mg} \cdot \mathrm{ha}^{-1}\right)$ are shown above bars in Middle Upper. All values are 3-y (2005-2007) means. Differences $(\Delta)$ and $t$ test significance for selected comparisons between factor levels are shown (n.s., not significant).

counterbalanced by extra fuel use for other field operations such as herbicide application (Table S4). Although applied $\mathrm{N}$ fertilizer was $21 \mathrm{~kg}$ of $\mathrm{N} \cdot \mathrm{ha}^{-1}$ less in maize-soybean rotations than under continuous maize, the associated rotation benefit on energy savings was not significant $(P=0.90)$ and small compared with the energy savings achieved with pivot irrigation or reduced tillage.

Of interest was the observation that management systems with the highest grain yield, NER, and NEY also had the lowest GWPi (i.e., pivot irrigation under soybean-maize rotation and reduced till). Differences in NEY due to crop rotation $\times$ tillage interactions were explained by variations in grain yield (Fig. 4). Whereas crop rotation had no detectable impact on NEY in conventional-tilled fields, NEY of maize after soybean was $7 \%$ higher than maize after maize in fields in which reduced tillage was practiced. On average, NER was $23 \%$ and $5 \%$ higher in fields under pivot and reduced tillage than under surface irrigation and conventional tillage, respectively. GWPi was $7 \%$ and $14 \%$ smaller in fields in a maize-soybean rotation and under pivot irrigation, respectively, compared with their counterparts under continuous maize and surface irrigation.

Potential to Reduce GHG Emissions from Maize Production Systems. A large decrease in GHG emissions per hectare of crop production would result from converting current irrigated cropland into dryland agriculture. However, this option has an unavoidable tradeoff of a 55\% reduction in grain yield and much greater yearto-year yield variability as shown by comparison of yields and yield variability of rainfed and irrigated maize in Tri-Basin NRD. Assuming elimination of irrigated maize production, the amount of additional maize area (in addition to all existing maize land area in Tri-Basin NRD) to replace this lost production would depend on yield level in the new production area. For example, based on current average rainfed yields, replacement would require 124,170 ha in Nebraska, 90,517 ha in Iowa, or 276,722 ha in Brazil. Additional land requirements, GHG emissions from land use change, and GHG emissions from crop production on this newly converted land would offset apparent benefits of expanding low-input/lowyield rainfed maize at the expense of irrigated maize in the TriBasin NRD.

Given concerns about land use, the most promising avenue to reduce GHG emissions, without significant impact on productivity, appears to be through improvements in input use efficiency of current irrigated maize systems. Among irrigated maize fields in the Tri-Basin NRD, lack of correlation between irrigated yields and energy input or GWP in all years, and three- and fourfold greater variation in energy inputs and GWP, respectively, than observed variation in grain yield (Fig. $3 A$ and $B$ ) suggest substantial scope to improve energy balance and to reduce GWP of irrigated maize without affecting productivity. Differences in both applied irrigation and magnitude of $\mathrm{N}$ surplus explained $57 \%$ of the variation in GWP. Therefore, achieving greater NUE and water productivity through better management of applied $\mathrm{N}$ and irrigation water would be most effective for increasing energy yield and reducing GHG emissions. Analysis of farmer's data indicated that values of NER and GWPi higher and lower than 6.5 and $218 \mathrm{~kg}$ of $\mathrm{CO}_{2} \mathrm{e} \cdot \mathrm{Mg}^{-1}$ of grain, respectively, can be set as reasonable energetic and environmental targets for irrigated maize (Fig. $3 A$ and $B$ ).

In fact, achieving high yield with large energy inputs and high input use efficiency resulted in a strong negative correlation between GWPi and NEY (Fig. 3C). This finding is consistent with results from a previous life cycle assessment for maizeethanol systems (5). There is, however, an important distinction between analyses based on Tri-Basin NRD irrigated maize data and previous published data. In the present study, NEY and GWPi were calculated based on: $(i)$ maize yield and input data collected during a recent 3-y time interval (2005-2007) across a large number of farmer's fields, (ii) the most recent embodiedenergy values for inputs to estimate energy balance and GHG emissions, and (iii) the $\mathrm{N}$-surplus approach to estimate soil $\mathrm{N}_{2} \mathrm{O}$ emissions. In contrast, previous studies relied on national- or statewide aggregated yield and applied input statistics, and the IPCC-N input approach to estimate soil $\mathrm{N}_{2} \mathrm{O}$ emissions. Also, the embodied-energy and GHG-emission values for specific inputs were not consistent across these previous studies and, in some cases, the values used are now obsolete and/or unrepresentative compared with current crop management practices and manufacturing efficiencies $(18,19)$.

The impact from adoption of best management practices, compared with current average management, on energy use and GWP was evaluated for irrigated maize in the Tri-Basin NRD (Table 2). Best management practices included use of low-pressure pivot irrigation, improved irrigation pump performance rating (PPPR), use of electrical power for irrigation water pumping rather than diesel or natural gas, fine-tuning of irrigation timing, and better $\mathrm{N}$ fertilizer management (see Materials and Methods for details on calculations and underpinning assumptions). Taken together, adoption of these management practices would result in a $25 \%$ and $21 \%$ reduction in energy use and GWP, respectively, with very little reduction in crop yield ( $4 \%$ reduction under limited irrigation; ref. 27). It is noteworthy that the greatest opportunity to reduce GHG emissions appears to be from fine-tuning $\mathrm{N}$ management practices aiming to reduce $\mathrm{N}$ surplus rather than reducing 
average $\mathrm{N}$ fertilizer rate. This proposition follows from the fact that, although many fields required higher or lower $\mathrm{N}$ fertilizer rates to achieve a zero $\mathrm{N}$ surplus (Fig. 1), the estimated average $\mathrm{N}$ rate for optimal $\mathrm{N}$ management is similar to the current average fertilizer $\mathrm{N}$ rate (178 vs. $183 \mathrm{~kg}$ of $\mathrm{N} \cdot \mathrm{ha}^{-1}$, respectively).

General Discussion. Increasing demand for food and fuel with limited reserves of arable land will require further intensification of existing cropping systems. At issue is whether it is possible to achieve an ecological intensification that gives both high yields and reduced environmental burden (20). Results from our study clearly document that high yield and high input-use efficiencies, together with low GWPi, are not conflicting goals in well-managed commercial-scale production fields. Although energy inputs and GWP per unit of land area were much greater in irrigated production compared with published values based mostly on rainfed maize production, associated NEY and GWPi of irrigated systems were substantially greater and lower, respectively. Hence, advantages of lower-input lower-yielding maize systems vanish when metrics are scaled by grain yield or net energy output. For this reason, assessments of energy efficiency and GWP metrics are most relevant when corrected for yield rather than on a landarea basis. For example, although energy inputs of irrigated maize in Tri-Basin NRD in Nebraska receive twice as much energy input as rainfed maize in Iowa (22), the extra energy inputs for irrigation and $\mathrm{N}$ fertilizer contribute to grain yields that are $23 \%$ greater $\left(13.2\right.$ and $10.7 \mathrm{Mg} \cdot \mathrm{ha}^{-1}$ ) and a $14 \%$ increase in NEY (159 and $139 \mathrm{MJ} \mathrm{ha}^{-1}$ ) than for rainfed maize in Iowa (Table S1).

Our results also showed large discrepancies between two methods for estimating $\mathrm{N}_{2} \mathrm{O}$ emissions from applied $\mathrm{N}$ inputs. Because current standard IPCC N-input method does not account for large variation in NUE observed across farmer's fields due to differences in yield level and competence in fertilizer management, estimated $\mathrm{N}_{2} \mathrm{O}$ emissions in high-yield, high-NUE irrigated maize fields in Tri-Basin NRD were much higher by using IPCC $\mathrm{N}$-input method than estimated by $\mathrm{N}$-surplus approach. Hence, the IPCC method to estimate $\mathrm{N}_{2} \mathrm{O}$ emissions based on a fixed proportion of applied $\mathrm{N}$ inputs (and assumptions regarding to amount of leached $\mathrm{N}$ and volatilized $\mathrm{N}$ described in SI Text, S2) is likely to overestimate $\mathrm{N}$ loses from well-managed, high-yield, high-input systems, such as irrigated maize in Nebraska. Moreover, the N-input approach cannot support incentives for investment in technologies to reduce $\mathrm{N}$ losses and, thereby, achieve better $\mathrm{N}$ balance without sacrificing yield. And although improved $\mathrm{N}$ management would result in only small energy savings because current average $\mathrm{N}$ rates are close to a zero net surplus, it would have a larger impact on reducing GHG emissions because of large

Table 2. Potential impact of adoption of best management practices on energy use and global warming potential in irrigated maize in Tri-Basin NRD

\begin{tabular}{lcc} 
Scenario & Total energy, $^{*}$ GJ & Total GWP, ${ }^{*} \mathrm{Mg}$ of $\mathrm{CO}_{2} \mathrm{e}$ \\
\hline Actual baseline $^{\dagger}$ & 28,758 & 2,745 \\
Potential $^{\ddagger}$ & 22,018 & 2,180 \\
Difference $^{\S}$ & $-6,741(-25 \%)$ & $-566(-21 \%)$ \\
\hline
\end{tabular}

See Materials and Methods for details on calculation of energy use and GWP under each scenario.

*Values are per 1,000 ha of irrigated maize in Tri-Basin NRD.

${ }^{\dagger}$ Based on actual frequency of fields under each type of irrigation system, tillage method, crop rotation, and source of energy for irrigation pumping "Based on full adoption of improved plant performance rating (90\%), use of electrical power for irrigation water pumping, pivot irrigation, limited-irrigation, and optimal $\mathrm{N}$ management in current irrigated maize land area that is not already under these management practices.

${ }^{\S}$ Absolute and relative (in parentheses) difference in energy use and GWP under the potential scenario compared with actual baseline. variation among fields in $\mathrm{N}$ surplus or deficit. This differential impact of improved $\mathrm{N}$ management on energy use versus GHG emissions would not be observed if the IPCC N-input approach is used to estimate $\mathrm{N}_{2} \mathrm{O}$ emissions.

In a broad context, irrigated maize production in Nebraska can be taken as a benchmark for other current and future irrigated cropping systems because it achieves remarkably high and stable grain yields, high efficiencies in use of solar radiation, $\mathrm{N}$, and water, and has a large positive energy balance and low GWPi. These findings are relevant for irrigated cropping systems worldwide that have good infrastructure and access to agricultural inputs, technologies and equipment, and information on how to use them. Other irrigated maize systems that fit these characteristics include those in France, Italy, Argentina, and Brazil. Over time, we would expect these supporting conditions to occur in other irrigated maize producing countries such as China, India, and elsewhere.

\section{Materials and Methods}

Tri-Basin Natural Resources Database. For the present study, we used a 3-y (2005-2007) database collected from irrigated maize fields in Tri-Basin NRD (southcentral Nebraska) containing farmer-provided data on grain yield, applied inputs ( $\mathrm{N}$ rate, applied irrigation water, seeding rate), and management practices (tillage method, irrigation system, energy source for ir rigation pumping) $(26,27)$. The database included a total of 123 field-years, representative of a much larger database that includes a total of 777 fieldyear observations collected in Tri-Basin NRD for the same time interval ( $S$ I Text, S1). Conversion efficiency from solar radiation to crop biomass, NUE, and crop water productivity were calculated for each site-year (SI Text, S1). These parameters, except NUE due to the lack of actual data, were also calculated for rainfed maize in Tri-Basin NRD (SI Text, S1).

Inventory of Energy Inputs. To estimate energy inputs for each of the 123 irrigated maize fields, energy values for manufacturing, packaging, and transportation of agricultural inputs were combined with farmer-reported input levels (fertilizer $\mathrm{N}$ rate, seeding rate, type of irrigation system, applied irrigation, and tillage method) and Nebraska state averages (30) for inputs not reported by farmers ( $\mathrm{P}$ and $\mathrm{K}$ fertilizer rates, herbicides, and insecticides) (SI Text, S3). The energy embodied in manufacturing, transportation, and repair of farm machinery was calculated for each tillage method (hereafter called "machinery"). Energy use for on-farm operations was calculated based on fuel use for field operations (including chopping stalks, fertilizing, tillage, cultivation, spraying, and harvesting), irrigation pumping, and grain drying (SI Text, S3). Energy use for field operations was calculated based on farmer-reported tillage method, type and number of field operations typically required under each tillage method, and associated fuel requirement. Energy use for irrigation pumping was calculated based on farmer-reported applied irrigation amount, energy source, and pumping depth. Labor required for on-farm operations and fuel use for transportation of grain from farm to an off-farm storage facility were not included in the energy inventory because they represented $<2 \%$ of total energy inputs (SI Text, S3).

For each field-year, energy input rate (GJ.ha ${ }^{-1}$ ) was calculated as the sum of annual fossil-fuel energy inputs. Several metrics to quantify energetic performance of cropping systems have been used in the published literature. To avoid redundancies, only NER (grain energy output-to-total energy input) and NEY (embodied energy in harvested grain minus total energy input; $\mathrm{GJ} \mathrm{ha}^{-1}$ ) are reported in the present study.

Calculation of Greenhouse Gas Emissions and Global Warming Potential. By following previous calculation of energy inventory, GHG emissions, including $\mathrm{CO}_{2}, \mathrm{CH}_{4}$, and $\mathrm{N}_{2} \mathrm{O}$ derived from fossil-fuel use for on-farm operations and production, transportation, and packaging of agricultural inputs and machinery, were calculated for each field (SI Text, S3). Additional $\mathrm{N}_{2} \mathrm{O}$ emissions from soil were estimated by following IPCC N-input-driven approach (23) or van Groenigen et al. N-surplus-driven approach (24) (SI Text, S2). Tillage method was assumed to have no effect on soil GHG emissions because there is no clear evidence for mitigation of soil GHG emissions using conservation tillage practices compared with conventional tillage $(31,32)$. Annual net change in soil carbon and soil $\mathrm{CH}_{4}$ emissions were assumed to be zero as found in a number of recent field studies on maize-based cropping systems in the US Corn Belt $(14,33,34)$.

The climate impact of GHG emissions was calculated as $\mathrm{CO}_{2} \mathrm{e}$, also called GWP (35). The 100-y GWP of $\mathrm{CH}_{4}$ and $\mathrm{N}_{2} \mathrm{O}$ are 25 and 298 times the intensity of $\mathrm{CO}_{2}$ on per mass basis, respectively. For each of the 123 irrigated maize 
fields, GWP ( $\mathrm{kg}$ of $\mathrm{CO}_{2} \mathrm{e} \cdot \mathrm{ha}^{-1}$ ) was calculated as the sum of $\mathrm{CO}_{2}, \mathrm{CH}_{4}$, and $\mathrm{N}_{2} \mathrm{O}$ emissions expressed as $\mathrm{CO}_{2} \mathrm{e}$. GWP intensity (GWPi; $\mathrm{kg}$ of $\mathrm{CO}_{2} \mathrm{e} \cdot \mathrm{Mg}^{-1}$ of grain) was calculated as the GWP-to-grain yield ratio (6).

Estimating Impact of Management Practices on Energy Balance and GHG Emissions. The 123 field-year observations were grouped into eight management categories that combine different irrigation systems (pivot and surface), crop rotation (continuous maize and maize-soybean rotation), and tillage methods [conventional disk till and reduced till (includes strip-, ridge-, and notill)]. To avoid biases due to random variation in sources of energy used for irrigation pumping across field-years, fuel for irrigation pumping under each category was assumed to be natural gas, diesel, and electricity in a 55:25:20 ratio, as observed in the larger 777 field-year database collected in Tri-Basin NRD (26).

The impact of energy-saving and GWP-reducing management practices was estimated per thousand hectares of irrigated maize. To do so, $100 \%$ adoption was assumed for the targeted practices on the proportion of total production area in the Tri-Basin NRD that was not already under such practices. ${ }^{+}$These practices include changes in PPPR $(90 \%$ vs. actual $80 \%)$, source of energy for pumping (electricity vs. natural gas or diesel), irrigation system (pivot vs. surface), irrigation scheduling (limited vs. actual irrigation), and $\mathrm{N}$ management ("optimal" vs. actual). Changes in crop rotation or tillage system were not analyzed because most irrigated maize land area in Tri-Basin NRD is already under soybean-maize rotation and reduced tillage $(61 \%$ and $78 \%$, respectively). PPPR is the ratio between required energy to pump a unit of water by properly designed and maintained pumping plants and actual energy use. PPPR is typically below $100 \%$ because of inadequate pump maintenance or because operating conditions have changed since the system was installed (typical PPPR for farmer-owned pumping plants in Nebraska is $80 \%$; SI Text

${ }^{\dagger}$ For example, the impact of $100 \%$ adoption of center pivots on energy use and GWP was calculated as the product of $(i)$ energy-use and GWP reduction derived from less applied irrigation water under pivot compared with surface irrigation, and (ii) surface-irrigated land area per thousand ha of irrigated maize.

1. Connor DJ, Loomis RS, Cassman KG (2011) Crop Ecology. Productivity and Management in Agricultural Systems (Cambridge Univ Press, Cambridge, UK).

2. Tilman D, Cassman KG, Matson PA, Naylor R, Polasky S (2002) Agricultural sustainability and intensive production practices. Nature 418:671-677.

3. West TO, Marland G (2002) A synthesis of carbon sequestration, carbon emissions, and net carbon flux in agriculture: Comparing tillage practices in the United States. Agric Ecosyst Environ 91:217-232.

4. Robertson GP, Grace PR (2004) Greenhouse gas fluxes in tropical and temperate agriculture: The need for a full-cost accounting of global warming potentials. Environ Dev Sustain 6:51-63.

5. Farrell $\mathrm{AE}$, et al. (2006) Ethanol can contribute to energy and environmental goals. Science 311:506-508.

6. Mosier AR, Halvorson AD, Reule CA, Liu XJJ (2006) Net global warming potential and greenhouse gas intensity in irrigated cropping systems in northeastern Colorado. J Environ Qual 35:1584-1598.

7. Searchinger TR, et al. (2008) Use of U.S. croplands for biofuels increases greenhouse gases through emissions from land-use change. Science 319:1238-1240.

8. Burney JA, Davis SJ, Lobell DB (2010) Greenhouse gas mitigation by agricultural intensification. Proc Natl Acad Sci USA 107:12052-12057.

9. de Wit CT (1992) Resource use efficiency in agriculture. Agric Syst 40:125-151.

10. Evans LT (1993) Crop Evolution, Adaptation, and Yield (Cambridge Univ Press, Cambridge, UK).

11. USDA-National Agricultural Statistics Service (NASS) Crops U.S. State and County Databases. Available at: http://www.nass.usda.gov/index.asp. Accessed March 1, 2011

12. Cassman KG, Dobermann A, Walters DT (2002) Agroecosystems, nitrogen-use effi ciency, and nitrogen management. Ambio 31:132-140.

13. Shapouri H, Duffield JA, Wang M (2003) The energy balance of corn ethanol revisited Trans ASAE 46:959-968.

14. Verma $S B$, et al. (2005) Annual carbon dioxide exchange in irrigated and rainfed maize-based agroecosystems. Agric For Meteorol 131:77-96.

15. Adviento-Borbe MAA, Haddix ML, Binder DL, Walters DT, Dobermann A (2007) Soil greenhouse gas fluxes and global warming potential in four high-yielding maize systems. Glob Change Biol 13:1972-1988.

16. Pimentel D, et al. (2008) Reducing energy inputs in the US food system. Hum Ecol 36 459-471.

17. Brussaard L, et al. (2010) Reconciling biodiversity conservation and food security: Scientific challenges for a new agriculture. Curr Opin Environ Sustain 2:34-42.

18. Pimentel D, Patzek T (2005) Ethanol production using corn, switchgrass, and wood; biodiesel production using soybean and sunflower. Nat Resour Res 14:165-176.

19. Patzek T (2004) Thermodynamics of the corn-ethanol biofuel cycle. Crit Rev Plant Sci 23:519-567.
S3). Replacement of natural gas or diesel by electrical power for pumping irrigation water was also considered because more work is produced per unit of energy delivered to the pump when electrical power is used, reducing the energy use per unit of applied water (Table S4). Compared with natural gas or diesel, the benefit of greater pump efficiency with electrical power more than offsets the higher GHG emissions from electrical power generation, which relies heavily on coal-fired power plants. Water savings under pivot irrigation, compared with surface irrigation, and under limited irrigated scheduling were retrieved from a previous study (27). Under limited irrigation, the amount of water applied is equivalent to $75 \%$ of full crop water demand throughout the cropping period except during growth stages especially sensitive to water stress $(-14$ to $+7 \mathrm{~d}$ window around silking), during which the crop is kept fully irrigated. Results from previous studies based on the same Tri-Basin NRD database indicate that limited irrigation can lead to irrigation-water savings of $22 \%$ compared with actual applied irrigation amounts currently used by farmers with pivot irrigation, with a small yield penalty of $4 \%$ with limited irrigation (27). We also explored the impact of adopting $\mathrm{N}$ management practices that would precisely balance the amount of $\mathrm{N}$ applied with the amount of crop N uptake (hereafter called "optimal" N management) under the assumption that achieving a zero- $\mathrm{N}$ surplus minimizes $\mathrm{N}$ losses without a decrease in soil organic carbon and $\mathrm{N}$ stocks. Such practices include adjustment of $\mathrm{N}$ fertilizer rates according to field-specific yield goal and indigenous $\mathrm{N}$ supply, and several smaller $\mathrm{N}$ doses with more timely applications that congruent with crop $\mathrm{N}$ demand (12). $\mathrm{N}$ rate under "optimal" $\mathrm{N}$ management was estimated as the amount of $\mathrm{N}$ in aboveground biomass at maturity minus nonfertilizer $\mathrm{N}$ inputs from irrigation water and manure (SI Text, S2).

ACKNOWLEDGMENTS. We thank Tri-Basin NRD board and staff, especially John Thorburn and Tammy Fahrenbruch, and University of Nebraska-Lincoln (UNL) extension educator Chuck Burr. Drs. Irmak and Kruger (UNL) provided information on farmer-owned pumping plants and grain drying, respectively. Support for this project came from Nebraska (NE) Corn Board Grant 56362 and the Water, Energy and Agriculture Initiative with funding from NE Corn Board, NE Soybean Board, Agricultural Research Division at UNL, and NE Public Power District.

20. Cassman KG (1999) Ecological intensification of cereal production systems: Yield potential, soil quality, and precision agriculture. Proc Natl Acad Sci USA 96:5952-5959.

21. Hülsbergen KJ, Feil B, Diepenbrock W (2002) Rates of nitrogen application required to achieve maximum energy efficiency for various crops: Results of a long-term experiment. Field Crops Res 77:61-76.

22. Liska AJ, et al. (2009) Improvements in life-cycle energy efficiency and greenhouse gas emissions of corn-ethanol. J Ind Ecol 13:58-74.

23. IPCC (2006) 2006 IPCC Guidelines for National Greenhouse Gas Inventories. Prepared by the National Greenhouse Gas Inventory Programme, Eggleston HS et al (Inst Glob Environ Strat, Hayama, Japan).

24. van Groenigen JW, Velthof G, Oenema O, van Groenigen KJ, van Kessel C (2010) Towards an agronomic assessment of N2O emissions: A case study for arable crops. Eur J Soil Sci 61:903-913.

25. Broadbent FE, Carlton AB (1978) Field trials with isotopically labeled nitrogen fertilizer. Nitrogen in the Environment, ed Nielsen DR (Academic, San Diego).

26. Grassini P, Thorburn J, Burr C, Cassman KG (2011) High-yield irrigated maize in the Western U.S. Corn-Belt: I. On-farm yield, yield-potential, and impact of management practices. Field Crops Res 120:142-150.

27. Grassini P, et al. (2011) High-yield irrigated maize in the Western U.S. Corn-Belt: II. Irrigation management and crop water productivity. Field Crops Res 120:133-141.

28. Lindquist JL, Arkebauer TJ, Walters DT, Cassman KG, Dobermann A (2004) Maize radiation use efficiency under optimal growth conditions. Agron J 97:72-78.

29. Yang HS, et al. (2004) Hybrid-Maize: A maize simulation model that combines two crop modelling approaches. Field Crops Res 87:131-154.

30. USDA-Economic Research Service (ERS) Crop production practices. Available at: http:// www.ers.usda.gov/Data/ARMS. Accessed March 1, 2011.

31. Grandy AS, Loecke TD, Parr S, Robertson GP (2006) Long-term trends in nitrous oxide emissions, soil nitrogen, and crop yields of till and no-till cropping systems. J Environ Qual 35:1487-1495.

32. Snyder CS, Bruulsema TW, Jensen TL, Fixen PE (2009) Review of greenhouse gas emissions from crop production systems and fertilizer management effects. Agric Ecosyst Environ 133:247-266.

33. Baker JM, Ochsner TE, Venterea RT, Griffis TJ (2007) Tillage and soil carbon sequestration-what do we really know? Agric Ecosyst Environ 118:1-5

34. Blanco-Canqui H, Lal R (2008) No-tillage and soil-profile carbon sequestration: An onfarm assessment. Soil Sci Soc Am J 72:693-701.

35. IPCC (2007) IPCC, Climate Change 2007: The Physical Science Basis. Contribution of Working Group I to the Fourth Assessment Report of the Intergovernmental Panel on Climate Change, eds Parry ML, et al. (Cambridge Univ Press, Cambridge, UK) 